\title{
PROBING THE FOG LIFE CYCLES IN THE NAMIB DESERT
}

\author{
Robert Spirig, Roland Vogt, Jarl Are Larsen, Christian Feigenwinter, Andreas Wicki, \\ Joel Franceschi, Eberhard Parlow, Bianca Adler, Norbert Kalthoff, Jan Cermak, \\ Hendrik Andersen, Julia Fuchs, Andreas Bott, Maike Hacker, Niklas Wagner, \\ Gillian Maggs-Kölling, Theo Wassenaar, and Mary Seely
}

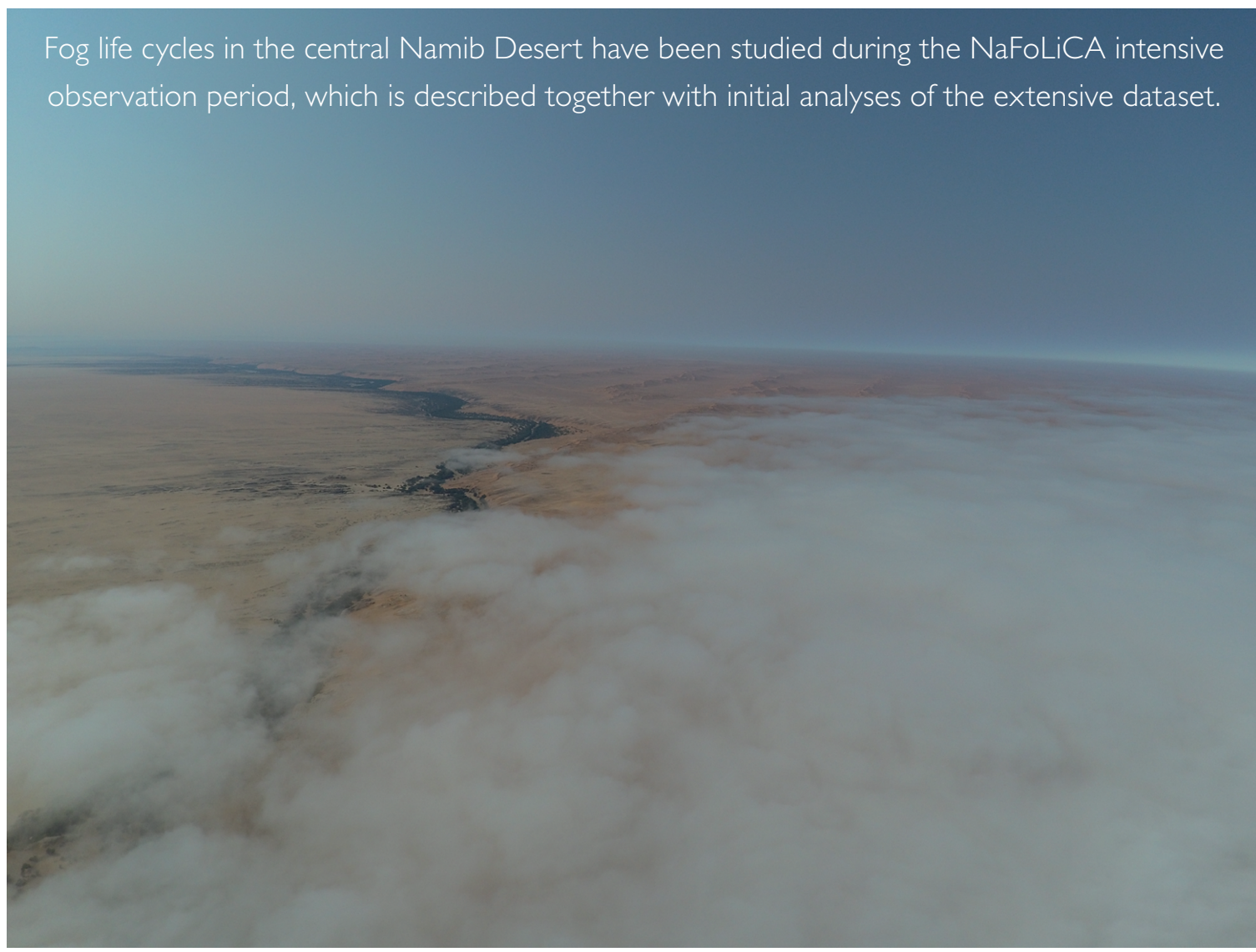

FIG. I. View across the fog boundary in Gobabeb toward the southeast from about $500 \mathrm{~m} \mathrm{AGL}$ at 0700 UTC 27 Sep 2017. The dark band of trees in the Kuiseb riverbed separates (right) the Namib Sand Sea from (left) the Gravel Plains.

$\mathrm{F}$

og as a meteorological phenomenon is associated with low visibility, high relative humidity/cold air, and danger for car/air traffic. However, in one of the driest regions on Earth—-the Namib Desert-fog instead represents a major source of water for plants and animals. Figure 1 illustrates this striking contrast between suspended water droplets of fog and dry desert.
The field campaign of the Namib Fog Life Cycle Analysis (NaFoLiCA) project was conducted during an intensive observation period (IOP) in SeptemberOctober 2017 in the central Namib Desert in Namibia. The aim of this IOP was to investigate the spatial and temporal patterns of the coastal fog, which occurs regularly in the central Namib 
during nighttime and morning hours reaching up to $100 \mathrm{~km}$ inland.

NAMIB DESERT. The Namib Desert is a relatively narrow strip of land extending $2,000 \mathrm{~km}$ from the Olifants River in South Africa $\left(32^{\circ} \mathrm{S}\right)$ to the Carunjamba River in Angola $\left(14^{\circ} \mathrm{S}\right)$. Bordered by the southern Atlantic Ocean and inland by the Great Western Escarpment, it is mostly between 120 and $200 \mathrm{~km}$ wide (Goudie and Viles 2015). Located on the west side of the African continent and adjacent to the cold Benguela Current, the Namib is a typical coastal desert similar to the Peruvian/Atacama Desert in South America (Meigs 1966; Warner 2004). At the eastern border of the Namib, annual rainfall is typically around $100 \mathrm{~mm}$ and decreases toward the coast to values $<<50 \mathrm{~mm}$ (Lancaster et al. 1984; Mendelsohn et al. 2002). In the hyperarid Namib, fog is a distinct climatological feature and an important source of water (Seely and Henschel 1998). Fog plays a crucial role in sustaining a biota, which could not exist based on the scarce and highly intermittent rainfall alone (Seely 1989; Hachfeld and Jürgens 2000; Warren-Rhodes et al. 2013).

FOG ORIGIN AND DYNAMICS. Fog in the Namib is closely linked to features of the general circulation above the southern Atlantic Ocean. The dynamics of the persistent low cloud deck over the eastern parts of the southern Atlantic Ocean are a

AfFiliations: Spirig, Vogt, Larsen, FeigenWinter, Wicki, Franceschi, ANd PARLOW-University of Basel, Basel, Switzerland; Adler, Kalthoff, Cermak, Andersen, and Fuchs-Karlsruhe Institute of Technology, Karlsruhe, Germany; BOTT, HACKER, AND WAGNER-University of Bonn, Bonn, Germany; MAGGS-KöLLING AND WASSENAAR - Gobabeb Research and Training Center, Walvis Bay, Erongo, Namibia; SeELY-Desert Research Foundation of Namibia, Windhoek, Khomas, Namibia ORCID: SPIRIG-0000-0002-0868-2806;

LARSEN-0000-0002-7038-8309; FEIGENWINTER—0000-0003-2447-5492; WICKI-0000-0003-2946-28I8; PARLOW—0000-0003-0020-337X; AdLeR -0000-0002-0384-7456; KalTHOFF-0000-0002-3322-7557; CerMaK-0000-0002-4240-595X; ANDERSEN-0000-0003-2983-8838; FUCHS-0000-0002-7137-2245

CORRESPONDING AUTHOR: Robert Spirig, r.spirig@unibas.ch

The abstract for this article can be found in this issue, following the table of contents.

DOI:10.II75/BAMS-D-18-0142.I

In final form 15 August 2019

(C)2019 American Meteorological Society

For information regarding reuse of this content and general copyright

information, consult the AMS Copyright Policy. consequence of the large-scale subsidence related to the South Atlantic Anticyclone and the cool sea surface temperatures, coinciding with the upwelling in the Benguela Current. Additionally, complex processes influence the cloud formation and cloud cover, such as aerosols, whose role is poorly understood and currently under investigation (Andersen and Cermak 2015; Adebiyi and Zuidema 2018; Fuchs et al. 2017, 2018). Subsequently, neither climatology nor weather models presently capture the complex meteorology in the southeast Atlantic properly (e.g., Stier et al. 2013). Recently, extensive coordinated campaigns probed the troposphere above the South Atlantic with the aim to address these knowledge gaps (Zuidema et al. 2016; Formenti et al. 2019). Off the Namibian coast, a persistent strong south wind blows (Nicholson 2010) and leads to low-level divergence near the coast, which is often associated with a coastal low that affects the inland transport of the stratus deck (Warner 2004). This inland advection typically starts after sunset and progresses farther during the first half of the night. The movement of the stratus front eastward is linked to winds from a northerly direction and blocks thermal winds coming from the east. The stratus deck varies in base height, thickness, density, and in spatial extent according to the meteorological conditions at its origin and during its development. If the stratus intercepts with the ascending terrain, it turns into fog. When and where this landfall occurs is influenced by the thermo-topographic wind systems described in Tyson and Seely (1980): sea-land breezes, plain-mountain/mountain-plain, and valley-mountain winds complicate the situation. Usually, before 0900 UTC the stratus/fog disappears inland (Fig. 1), while close to the coast it can be more persistent. This Namib fog life cycle is a well-known characteristic of the central Namib, which consists of the central Gravel Plains in the north and the Namib Sand Sea (UNESCO World Heritage) in the south separated by the Kuiseb River (Fig. 2).

Various types of fog can be found in the central Namib. Near the coast in Walvis Bay, fog was described as either inversion fog, advection fog, or radiation fog (Jackson 1941). The latter two were also reported in Swakopmund $(30 \mathrm{~km}$ north of Walvis Bay) with a peak in fog days from April to August/ September (Nagel 1962). Inland at Gobabeb, advection fog or cloud interception fog is described as the prevailing fog type in austral summer (Olivier 1992). This cloud interception fog, also called high fog, is the result of the stratus deck intercepting the terrain which is described as a dynamic interaction of air masses from the east (Great Escarpment) and 
the northwest (coast/sea) by Seely and Henschel (1998). While the advection process is established in literature, the drivers and dynamics of it are not clearly defined. Radiation fog was not excluded per se but described as a possible exception (e.g., Seely and Henschel 1998; Olivier 1992) or was reported as an opportunistic observation (Eckardt et al. 2013; Kimura 2005). However, Kaseke et al. (2017) recently presented their findings based on isotope analysis of fog water sampled in the central Namib. More than half of their measured isotopic signatures are interpreted as locally generated fog water and the authors suggest "a potential shift from advectiondominated fog to radiation-dominated fog in the fog zone of the Namib Desert." Visualizations of the fog events using a synopsis of ground measurements and remote sensing data indicate that fog events inland are practically always connected to an advected stratus of marine origin (see "Fog goes movie" sidebar). Whether the mixing with local humidity and the local generation of fog during the landfall of the advected stratus causes the freshwater isotopic signature, which may be linked to radiation fog, is just one of the many interesting questions related to the Namib fog.

NAMIB FOG LIFE CYCLE ANALYSIS. To address such open questions about the dynamics and drivers of the fog, the Namib Fog Life Cycle Analysis (NaFoLiCA) project was initiated. It is concerned with the analysis of fog processes in the Namib Desert, an extremely dry region where the fog is an important component in the hydrological cycle. NaFoLiCA has to cross scales and take microphysical and macrophysical processes/properties of fog into account to $14.5^{\circ} \mathrm{E}$

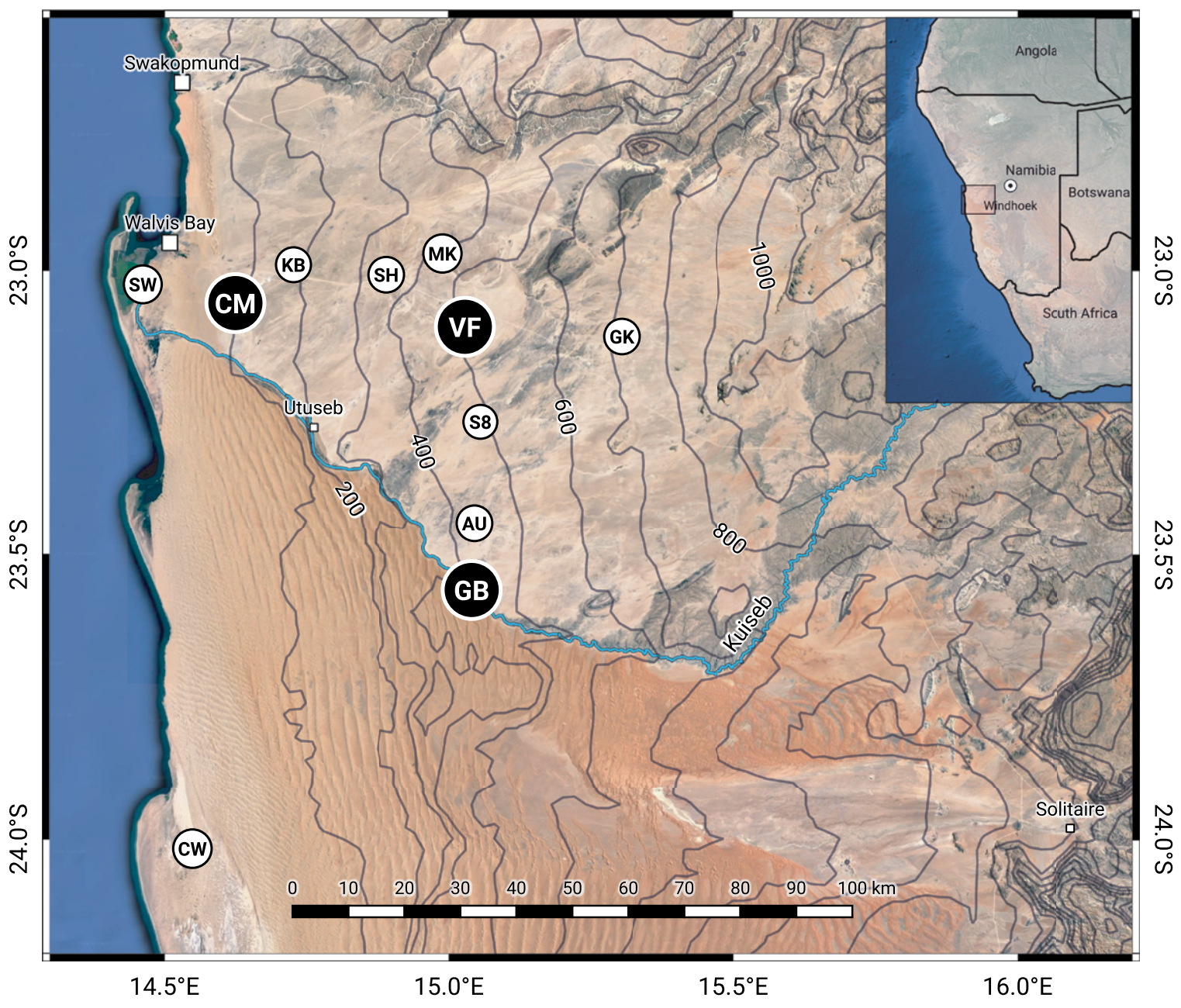

FIG. 2. Research area in the central Namib and locations of the FogNet stations (Table I). Black markers indicate where the main NaFoLiCA IOP activities took place. Contour line interval is $100 \mathrm{~m}$ and derived from SRTM, background imagery is from Google Maps. Map inset shows the research area in the larger context of southern Africa. 


\section{FOG GOES MOVIE}

The spatial and temporal patterns of fog in the Namib

are difficult to capture from ground-based point measurements only. Another solution is the combination of satellite remote sensing data with the groundbased data into an animated product. The so-called dust composite from Meteosat, which allows one to distinguish stratus/fog, are merged with FogNet data (wind, fog precipitation) into a video sequence. The product has been created for the whole IOP and can be found at https://mcr.unibas.ch/nafolicaiop. Within the $\mathrm{NaFoLiCA}$ satellite project, a quantitative product has been developed (Andersen and Cermak 2018) and will be used for joint analysis of the fog situations.

understand how temporal and spatial patterns of fog develop. This is done in a suite of complementary partner projects (i) by a field-based perspective using in situ observations and ground-based remote sensing at several locations in the region, (ii) by considering satellite data to characterize the spatial extent of fog and changes therein over time (Andersen and Cermak 2018; Andersen et al. 2019), and (iii) by providing a numerical modeling perspective and combining process insight with spatial information. Each project partner requires ground measurements of the vertical structure of the fog to understand its life cycle better and apply their various methods.

INTENSIVE OBSERVATION PERIOD. An important goal of the NaFoLiCA field campaign was to observe the life cycles of at least three inland-reaching fog events in detail at both a coastal and an inland location during the IOP. We define such nights as intensive observation night (ION). We took advantage of already-existing research infrastructure in the central Namib (FogNet; Muche et al. 2018) and conducted measurements at three FogNet sites (Fig. 2, Table 1) to provide a basic dataset for the three NaFoLiCA components: field measurements, satellite remote sensing, and fog modeling. This included the sampling of ground fog properties (droplet size and distribution) as well as vertical profiles of (derived potential) temperature, humidity, wind direction and speed, mixing layer height, cloud base/top height, aerosol optical depth, liquid water path (LWP), integrated water vapor, and stability indices. In the following, we give an overview of the experimental details of the IOP and present initial results focusing on one typical fog life cycle observed during the IONs.

In the context of the field campaign presented here, we focus on several questions related to different aspects of fog in the Namib within the wider NaFoLiCA project. We investigate how much water deposition takes places during fog events and whether these estimates by microlysimeters are reliable. We assess if fog collectors can serve as proxies for this deposition. Furthermore, we investigate the feasibility of combining cloud droplet spectra and turbulence measurements to derive the liquid water flux and its relation to the two other fog water measurements. On a larger scale, we investigate the vertical and spatial structure of the stratus, respectively fog and with the example of one specific event at selected locations. A synergetic analysis will be presented at a later stage.

FIELD CAMPAIGN DESIGN. Measuring fog in the desert. Fog climatology led us to place the IOP in early spring when the frequency of inland-reaching fog is highest (see "Fog climatology in the Namib" sidebar). The IOP with fully operational devices lasted from 10 September until 5 October 2017. The logistical basis for the IOP was the Gobabeb Research and Training Centre (gobabebtrc.org),

\begin{tabular}{|c|c|c|c|c|c|}
\hline Name & & Lat $\left({ }^{\circ}\right)$ & Lon $\left({ }^{\circ}\right)$ & $\begin{array}{l}\text { Elevation } \\
\text { (m MSL) }\end{array}$ & $\begin{array}{l}\text { Distance to } \\
\text { coast }(\mathbf{k m})\end{array}$ \\
\hline Coastal Met & CM & -23.06 & 14.63 & 94 & 17 \\
\hline Gobabeb & GB & -23.56 & 15.04 & 406 & 56 \\
\hline Vogelfederberg & VF & -23.10 & 15.03 & 515 & 58 \\
\hline Saltworks & SW & -23.02 & 14.46 & 5 & I \\
\hline Conception Water & $\mathrm{CW}$ & -24.02 & 14.55 & 10 & 10 \\
\hline Kleinberg & KB & -22.99 & 14.74 & 185 & 24 \\
\hline Sophies Hoogte & $\mathrm{SH}$ & -23.01 & 14.89 & 342 & 40 \\
\hline Aussinanis & $\mathrm{AU}$ & -23.44 & 15.05 & 444 & 55 \\
\hline Marble Koppie & MK & -22.97 & 14.99 & 419 & 51 \\
\hline Station 8 & S8 & -23.27 & 15.06 & 490 & 55 \\
\hline Garnet Koppie & GK & -23.12 & $|5.3|$ & 733 & 85 \\
\hline
\end{tabular}


a hot spot of desert research in the central Namib and operator of FogNet. The stations (Fig. 2) form a west-east transect with increasing elevation from the coast to $85 \mathrm{~km}$ inland and a north-south transect at $400-500 \mathrm{~m}$ above mean sea level (MSL), where the inland-reaching stratus frequently intercepts. The purpose of FogNet is to provide basic meteorological measurements and to monitor the occurrence of fog. At all FogNet stations air temperature $\left(T_{a}\right)$, relative humidity $(\mathrm{RH})$, wind speed (WS), wind direction (WD), global radiation $\left(R_{\mathrm{sd}}\right)$, and net radiation $\left(R_{n}\right)$ are available since June 2014 as 1-min averages (Table 2). Measurements of longwave downward radiation $\left(R_{\mathrm{ld}}\right)$ exist at coastal sites (Saltworks, Coastal Met, Conception Water) and at Gobabeb where four-component net radiometers are installed. The $R_{n}$, and even more $R_{\mathrm{ld}}$, are excellent indicators for the occurrence of stratus/ fog but allow no distinction between the two. And while the surface temperatures $\left(T_{s}\right)$ measured at the FogNet sites are helpful, the clearest indicator of whether or not fog occurred is the measurement of fog precipitation. Visibility measurements were available from the Gobabeb Baseline Surface Radiation Network (BSRN) station (Driemel et al. 2018).

Measuring fog water input. In case of the FogNet stations, Juvik fog collectors are installed. These consist of a cylindrical screen mounted above a rain gauge into which the fog water deposited on the screen drips and is measured by a tipping bucket. The collectors are made of louvered aluminum with a size of $12 \mathrm{~cm} \times 58 \mathrm{~cm}$ (diameter $\times$ height) and are described in detail in Juvik and Nullet (1995). The catch is called fog precipitation (FP) and is a rather qualitative measure for fog deposition as it depends on the screen's silhouette area exposed to the flow and its material properties. Fog deposition is the amount of fog water reaching the ground and as

\section{FOG CLIMATOLOGY IN THE NAMIB}

[ $\mathrm{og}$ is a reliable feature of the climate of the coastal Namib with I distinct spatial and seasonal characteristics. The average annual fog day frequency (FDF) decreases from the coast with values around 120 to around 40 at $40 \mathrm{~km}$ inland down to 5 at $100 \mathrm{~km}$ (Olivier 1992). Numbers reported differ slightly depending on whether FDF has been derived from visual observations (Nagel 1959; Olivier 1992) or from fog precipitation measurements (Nieman et al. 1978; Lancaster et al. 1984). For Pelican Point close to Walvis Bay, the highest value of average annual FDF is observed: 146.5 days in 27 years (1958-85) with $26.8,105$, and 200 days as standard deviation, minimum, and maximum (Olivier 1992). The inland decrease in FDF is supported by satellitederived spatial patterns of fog/low cloud occurrence (Olivier 1995; Cermak 2012; Andersen and Cermak 2018). The observations show also a latitudinal variation at the coast with high values in the area of Swakopmund/Walvis Bay decreasing to the north and south and an overall correlation with topography, that is, a decrease of FDF with heights up to around $800 \mathrm{~m}$ MSL.

The seasonal fog day distribution is characterized by the transition of the winter maximum of the monthly FDF at the coast to a spring/ summer maximum farther inland (Nagel 1959; Lancaster et al. 1984; Olivier 1992). The long-term observations at the first order weather station in Gobabeb represent the seasonality of FDF farther inland (Fig. SBI). Despite the high interannual variability, there is a clear winter minimum from April to June and a broad spring/summer maximum starting in September

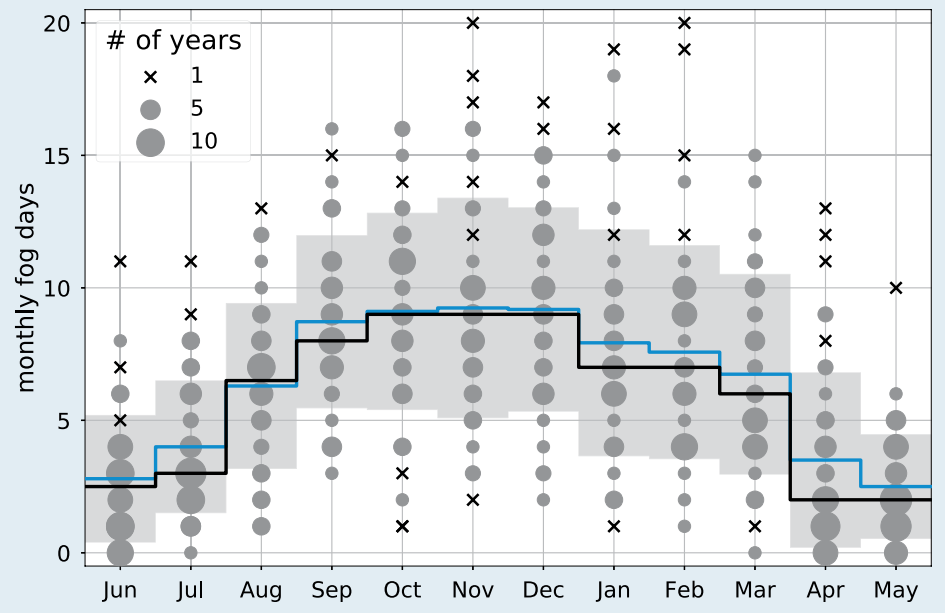

FIG. SBI. Average monthly fog days (1963-2016) in Gobabeb. Values are derived from the visual observations of fog and visibility at 0800 local standard time at the first order weather station: average (black line), median (blue line), and standard deviation (gray area). Gray circles show the distribution of monthly fog days over all years. Dot size is scaled by the number of years with the respective amount of fog events, for example, 10 years with one fog day observed in June. A cross indicates a single year with the respective number of fog days. such the proper hydrological variable. During the IOP, three pairs of microlysimeters were installed at three FogNet sites to measure fog deposition directly 
(Table 2). The homemade microlysimeters are constructed according to Heusinkveld et al. (2006) and measure non-rainfall water input (NRWI), which includes dewfall and adsorption of water vapor in addition to fog deposition. NRWI is derived from the weight increase measured by the microlysimeter relative to the minimum of the diurnal course and is attributed to fog deposition as supported by other measurements. The calculation of the liquid water flux (LWF) is another approach to sample fog water deposition (Burkard et al. 2001). LWF can be derived from high-frequency measurements of the

\begin{tabular}{|c|c|c|c|}
\hline $\begin{array}{l}\text { Output variable(s) } \\
\text { (abbreviation) }\end{array}$ & $\begin{array}{l}\text { Device(s), } \\
\text { manufacturer, } \\
\text { and short name, if used }\end{array}$ & $\begin{array}{l}\text { Measurement } \\
\text { height } \\
\text { (m AGL) }\end{array}$ & Location \\
\hline Fog precipitation (FP) & $\begin{array}{l}\text { Juvik fog collector, } \\
\text { Constructed after Juvik and Nullet (1995) }\end{array}$ & 1.5 & GB \\
\hline Visibility (Vis) & $\begin{array}{l}\text { Atmospheric visibility monitor CSI20A, } \\
\text { Campbell Scientific }\end{array}$ & 1.5 & GB \\
\hline $\begin{array}{l}\text { Radiation components }\left(R_{\mathrm{sd}}, R_{\mathrm{ld}}\right) \\
\text { net radiation }\left(R_{\mathrm{n}}\right)\end{array}$ & $\begin{array}{l}\text { Net Radiometer CNR4, } \\
\text { Kipp \& Zonen }\end{array}$ & 2.0 & GB \\
\hline $\begin{array}{l}\text { Air temperature }\left(T_{a}\right) \\
\text { relative humidity }(\mathrm{RH})\end{array}$ & $\begin{array}{l}\text { Temperature and relative humidity probe CS215, } \\
\text { Campbell Scientific }\end{array}$ & 2.0 & GB \\
\hline Surface temperature $\left(T_{s}\right)$ & $\begin{array}{l}\text { Radiometer IRI20, } \\
\text { Campbell Scientific }\end{array}$ & 1.9 & GB \\
\hline Wind direction and speed (WD, WS) & $\begin{array}{l}\text { Wind Monitor, } \\
\text { R. M. Young }\end{array}$ & 10.0 & GB \\
\hline $\begin{array}{l}\text { Droplet distribution, } \\
\text { liquid water content (LWC), } \\
\text { liquid water flux (LWF) with sonic }\end{array}$ & $\begin{array}{l}\text { Cloud droplet probe, } \\
\text { Droplet Measurement Techniques, } \\
\text { CDP }\end{array}$ & 2.0 & GB \\
\hline $\begin{array}{l}u, v, w \text { wind components, } \\
\text { fluxes of } \mathrm{CO}_{2} \text {, sensible, and } \\
\text { latent heat (fluxes listed for completion) }\end{array}$ & $\begin{array}{l}\text { IRGASON: Integrated gas analyzer and sonic anemometer, } \\
\text { Campbell Scientific }\end{array}$ & 2.0 & GB \\
\hline $\begin{array}{l}\text { Non-rainfall water input (NRWI) } \\
\text { by net weight change }\end{array}$ & $\begin{array}{l}\text { Microlysimeters, } \\
\text { Self-constructed after Heusinkveld et al. (2006) }\end{array}$ & $\begin{array}{l}-0.35 \\
\text { to } \\
0.0\end{array}$ & $\begin{array}{l}\text { GB } \\
V F \\
C M\end{array}$ \\
\hline $\begin{array}{l}\text { Air temperature }\left(T_{a}\right) \\
\text { relative humidity }(\mathrm{RH}) \\
\text { wind direction and speed (WD, WS), } \\
\text { pressure }\end{array}$ & $\begin{array}{l}\text { Weather station, } \\
\text { Vaisala }\end{array}$ & 2.0 & CM \\
\hline Wind direction and speed (WD, WS) & $\begin{array}{l}\text { Flat Array SOnic Detection And Ranging MFAS, } \\
\text { Scintec, } \\
\text { SODAR }\end{array}$ & $\leq 900$ & $\begin{array}{l}\text { GB } \\
\text { CM }\end{array}$ \\
\hline $\begin{array}{l}\text { Backscatter }(\mathrm{BS}) \\
\text { mixing layer height }(\mathrm{MLH}) \\
\text { cloud base height }(\mathrm{CBH})\end{array}$ & $\begin{array}{l}\text { Ceilometers CSI35 and CL3I, } \\
\text { CM: Vaisala (Wiegner et al. 20I9, CL3I-2), } \\
\text { GB: Campbell Scientific, } \\
\text { ceilometer }\end{array}$ & $\begin{array}{l}\leq 7,700 \\
\leq 10,240\end{array}$ & $\begin{array}{l}\mathrm{CM} \\
\mathrm{GB}\end{array}$ \\
\hline $\begin{array}{l}\text { Profile of air temperature }\left(T_{a}\right) \text {, } \\
\text { liquid water path (LWP), } \\
\text { integrated water vapor }\end{array}$ & $\begin{array}{l}\text { Microwave radiometer (Kalthoff et al. 2013), } \\
\text { Radiometer Physics }\end{array}$ & $\leq 10,000$ & CM \\
\hline $\begin{array}{l}\text { Air temperature }\left(T_{a}\right) \\
\text { relative humidity }(\mathrm{RH}) \\
\text { wind direction and speed (WD, WS) }\end{array}$ & $\begin{array}{l}\text { Tethered balloon sonde carrying a cup anemometer and } \\
\text { an air temperature/relative humidity/pressure probe, } \\
\text { self-constructed, } \\
\text { TBS }\end{array}$ & $\leq 800$ & $\begin{array}{l}\mathrm{GB} \\
\mathrm{CM}\end{array}$ \\
\hline $\begin{array}{l}\text { Air temperature }\left(T_{a}\right) \\
\text { relative humidity }(\mathrm{RH})\end{array}$ & $\begin{array}{l}\text { Radiosonde DFM-09 } \\
\text { on balloon } \\
\text { on UAV } \\
\text { Graw }\end{array}$ & $\begin{array}{l}\leq 20,000 \\
\leq 800\end{array}$ & $\begin{array}{c}\mathrm{GB} \\
\mathrm{VF}, \mathrm{GB}\end{array}$ \\
\hline
\end{tabular}


vertical wind component and the liquid water content (LWC in $\mathrm{g} \mathrm{m}^{-3}$ ) by applying the eddy-covariance method (Aubinet et al. 2012). Droplet distribution was measured by a Cloud Droplet Probe (CDP), which allows for calculation of droplet concentration from wind speed, for example, a wind speed of $1 \mathrm{~m} \mathrm{~s}^{-1}$ results in a volume of $0.298 \mathrm{~cm}^{3} \mathrm{~s}^{-1}$ passing through the sample area with the correspond-

ing measured number of size-resolved droplets. LWC in turn is derived from this concentration by assuming a water density of $1 \mathrm{~g} \mathrm{~cm}^{-3}$ and a spherical form of droplets (Droplet Measurement Technologies 2012). LWF is calculated as the mean (indicated by overbar) of $\overline{w^{\prime} \mathrm{LWC}}$ where $w$ is the vertical wind component and the prime denotes the deviation from the average.

Stratus and fog in the air. Measurements carried out manually during the IOP (Table 2) comprised the launch of radiosondes, an unmanned aerial vehicle (UAV) equipped with a radiosonde and a tethered balloon sonde (TBS). The radiosondes were released only at Gobabeb at set intervals to observe background wind, air temperature, and humidity above the stratus/fog layer. With the UAV and the TBS, the vertical structure of the stratus/fog layer was probed. A radiosonde taped to the stands of the UAV with the sensor element fixed to a mini-boom was lifted up to $800 \mathrm{~m}$ above ground level (AGL) to measure profiles of air temperature, humidity, and the height AGL. An ascent and descent took approximately $15 \mathrm{~min}$. The TBS sampled profiles of pressure, air temperature, dewpoint temperature, and wind speed and wind direction, and was attached to a $5-\mathrm{m}^{3}$ balloon, which went up to $600 \mathrm{~m}$ AGL. Soundings consisting of ascents and descents were made in 60-min intervals and controlled manually with an electric winch. After each descent, the sonde was allowed to equilibrate at the ground for a short time. For the first four IONs, profiles were sampled at Vogelfederberg and Gobabeb while Coastal Met was only included for the last ION (Table 3). An ION started with a radiosonde launch at 1700 UTC and lasted with continuous ascents and descents of TBSand UAV-probing through the night until 0730 UTC.

Vertical profiles of wind speed and wind direction were sampled with two sodars, one at Coastal Met (30-m vertical resolution) and one inland at Gobabeb (10-m vertical resolution) as 30 -min averages. The maximum valid vertical range varied between 300 and $800 \mathrm{~m}$ AGL depending on atmospheric conditions. One passive microwave radiometer was operated at Coastal Met to measure LWP and the vertical temperature field up to $10 \mathrm{~km}$ AGL. Two ceilometers installed at Coastal Met and Gobabeb delivered cloud base height $(\mathrm{CBH})$, laser backscatter (BS), and mixing layer height (MLH).

INITIAL RESULTS. Synoptic conditions and fog events during the IOP. The synoptic setting during the IOP was characterized by only mildly disturbed conditions (Tyson and Preston-Whyte 2000): the subtropical southern Atlantic anticyclone lay southwest of the Namibian coast and the African thermal low was located to the northeast. The zonal pressure gradient was dominant offshore of Namibia and varied only slightly, induced by passages of westerly waves. Southeast trade winds were blowing steadily, closer to the coast from the south, and low-level divergence together with a weak coastal low, which was present offshore the central Namib most of the time, supported the inland transport of the marine stratus layer. In this situation, 22 fog days with measured fog precipitation occurred in the study area out of 25 IOP days (Table 4). At Vogelfederberg 18 fog events with on average $2.6 \mathrm{~mm}$ of $\mathrm{FP}$ were registered while at Coastal Met 12 fog events with $0.46 \mathrm{~mm}$ per event were recorded. In Gobabeb 14 fog events with 0.96 mm occurred, which meant twice the fog days we could expect from climatology in September (Fig. SB1 in "Fog climatology in the Namib" sidebar) and allowed us to meet our criteria of sampling at least three inland reaching fog events during the IOP.

Meteorological conditions during the IOP. Inland at Gobabeb, the daytime maximum air temperatures (Fig. 3a) during the IOP reached only around $25^{\circ} \mathrm{C}$, 
TABLE 4. Amounts of fog precipitation and NRWI at the three IOP sites Coastal Met, Vogelfederberg, and Gobabeb during nights with at least one station detecting fog. For Gobabeb minimum visibility and time of visibility below the fog threshold of I km is listed. The five IONs are marked in bold.

\begin{tabular}{|c|c|c|c|c|c|c|c|c|}
\hline \multirow[t]{3}{*}{ Night } & \multicolumn{2}{|c|}{ CM } & \multicolumn{2}{|c|}{$\underline{\text { VF }}$} & \multicolumn{4}{|c|}{ GB } \\
\hline & FP & NRWI & FP & NRWI & FP & NRWI & Vis & Vis $\leq \mathrm{I} \mathbf{k m}$ \\
\hline & \multicolumn{6}{|c|}{$(\mathrm{mm})$} & $(\mathrm{km})$ & (H:MM) \\
\hline 10-II Sep & 0.04 & 0.28 & 1.51 & 0.21 & 1.20 & 0.47 & 0.12 & $7: 49$ \\
\hline II-12 Sep & 0.47 & 0.48 & - & 0.16 & - & 0.10 & 0.25 & $0: 36$ \\
\hline $12-13 \mathrm{Sep}$ & 0.12 & 0.59 & 4.00 & 0.99 & 0.35 & 0.65 & 1.52 & - \\
\hline 13-14 Sep & 1.09 & $0.4 I$ & 0.12 & 0.14 & - & 0.79 & 1.81 & - \\
\hline $14-15$ Sep & - & 0.23 & 2.02 & 0.25 & 0.47 & 0.23 & 1.16 & - \\
\hline $15-16 \mathrm{Sep}$ & - & 0.17 & - & 0.10 & - & 0.05 & 18.72 & - \\
\hline $16-17 \mathrm{Sep}$ & - & 0.20 & 4.03 & 0.40 & 1.24 & 0.18 & 0.12 & $6: 34$ \\
\hline 17-18 Sep & 0.16 & 0.47 & 6.36 & 0.43 & 1.98 & 0.14 & 0.14 & $6: 53$ \\
\hline 18-19 Sep & 0.04 & 0.47 & 3.34 & 0.65 & 0.23 & 0.22 & 0.19 & $3: 38$ \\
\hline 19-20 Sep & - & 0.23 & 3.26 & 0.30 & 1.75 & 0.12 & 0.12 & $2: 53$ \\
\hline 20-2I Sep & - & 0.15 & 0.39 & 0.14 & 0.04 & 0.11 & 0.25 & $\mathrm{I}: 22$ \\
\hline $21-22 \mathrm{Sep}$ & 0.93 & 0.73 & 2.56 & 0.33 & 0.19 & 0.22 & 0.27 & $\mathrm{I}: 25$ \\
\hline 22-23 Sep & 0.54 & 0.25 & - & 0.07 & - & 0.06 & 11.62 & - \\
\hline 23-24 Sep & 0.62 & 0.46 & 1.63 & 0.10 & - & 0.10 & 0.90 & $0: 01$ \\
\hline 24-25 Sep & 0.97 & 0.88 & 2.95 & 0.54 & 0.54 & 0.36 & 0.41 & $0: 59$ \\
\hline $25-26 \mathrm{Sep}$ & 0.23 & 0.27 & - & 0.18 & - & 0.07 & 14.64 & - \\
\hline $26-27 \mathrm{Sep}$ & - & 0.22 & 5.62 & $0.4 I$ & 1.12 & 0.07 & 0.12 & $3: 30$ \\
\hline 27-28 Sep & - & 0.14 & 3.18 & 0.38 & 1.20 & 0.16 & 0.15 & $5: 14$ \\
\hline 28-29 Sep & 0.35 & 0.25 & - & 0.11 & - & 0.08 & 10.92 & - \\
\hline 29-30 Sep & - & 0.21 & 0.08 & 0.14 & - & 0.08 & 0.50 & $0: 08$ \\
\hline 30 Sep-I Oct & - & 0.18 & 0.50 & 0.31 & 1.20 & 0.18 & 0.14 & $5: 00$ \\
\hline $\mathrm{I}-2 \mathrm{Oct}$ & - & 0.19 & 5.00 & 0.30 & 1.86 & 0.14 & 0.16 & $4: 46$ \\
\hline $2-3$ Oct & - & 0.14 & 0.74 & 0.17 & - & 0.09 & 14.22 & - \\
\hline $3-4$ Oct & - & 0.16 & - & 0.19 & - & 0.01 & 6.07 & - \\
\hline 4-5 Oct & - & 0.65 & - & 0.12 & - & 0.08 & 4.25 & 一 \\
\hline
\end{tabular}

which emphasizes the influence of the sea breeze advecting cooler air. At night, air temperatures decreased to around $10^{\circ} \mathrm{C}$. The presence of stratus/fog reduced the cooling rate to almost zero, resulting in surface temperatures of around 2-3 K higher compared to air temperature. Clear nights had the opposite effect and surface cooling continued until sunrise.

Relative humidity decreased to around 30\% during daytime and reached between $70 \%$ and $90 \%$ during clear nights (Fig. 3a). Specific humidity in Gobabeb exhibited a variation of $\pm 1 \mathrm{~g} \mathrm{~kg}^{-1}$ around the values of $8 \mathrm{~g} \mathrm{~kg}^{-1}$ before and $7 \mathrm{~g} \mathrm{~kg}^{-1}$ after 26 September with no obvious connection to fog events. Close to the coast, maximum air temperatures reached between $15^{\circ}$ and $20^{\circ} \mathrm{C}$ (not shown); nocturnal air temperatures, in turn, were $2 \mathrm{~K}$ higher compared to Gobabeb. Specific humidity at Coastal Met was similar or slightly (»1 $\mathrm{g} \mathrm{kg}^{-1}$ ) higher than inland.

In clear nights at Gobabeb, values of longwave downward radiation decreased to around $300 \mathrm{~W} \mathrm{~m}^{-2}$ while stratus/fog caused sharp increases of $R_{\mathrm{ld}}$ to plateaus between 360 and $375 \mathrm{~W} \mathrm{~m}^{-2}$ (Fig. 3b). Maxima of diffuse (global) shortwave radiation were smaller (larger) after 26 September, which corresponds to the change in specific humidity. The final dissipation of the stratus/fog layer in the morning can be derived by diffuse and global radiation.

The wind in Gobabeb illustrates the typical mix between the thermo-topographic wind regimes. After sunrise, the sea breeze develops with a daytime transition from northwest to southwest as reported in Tyson and Seely (1980). On several days, the plain- 

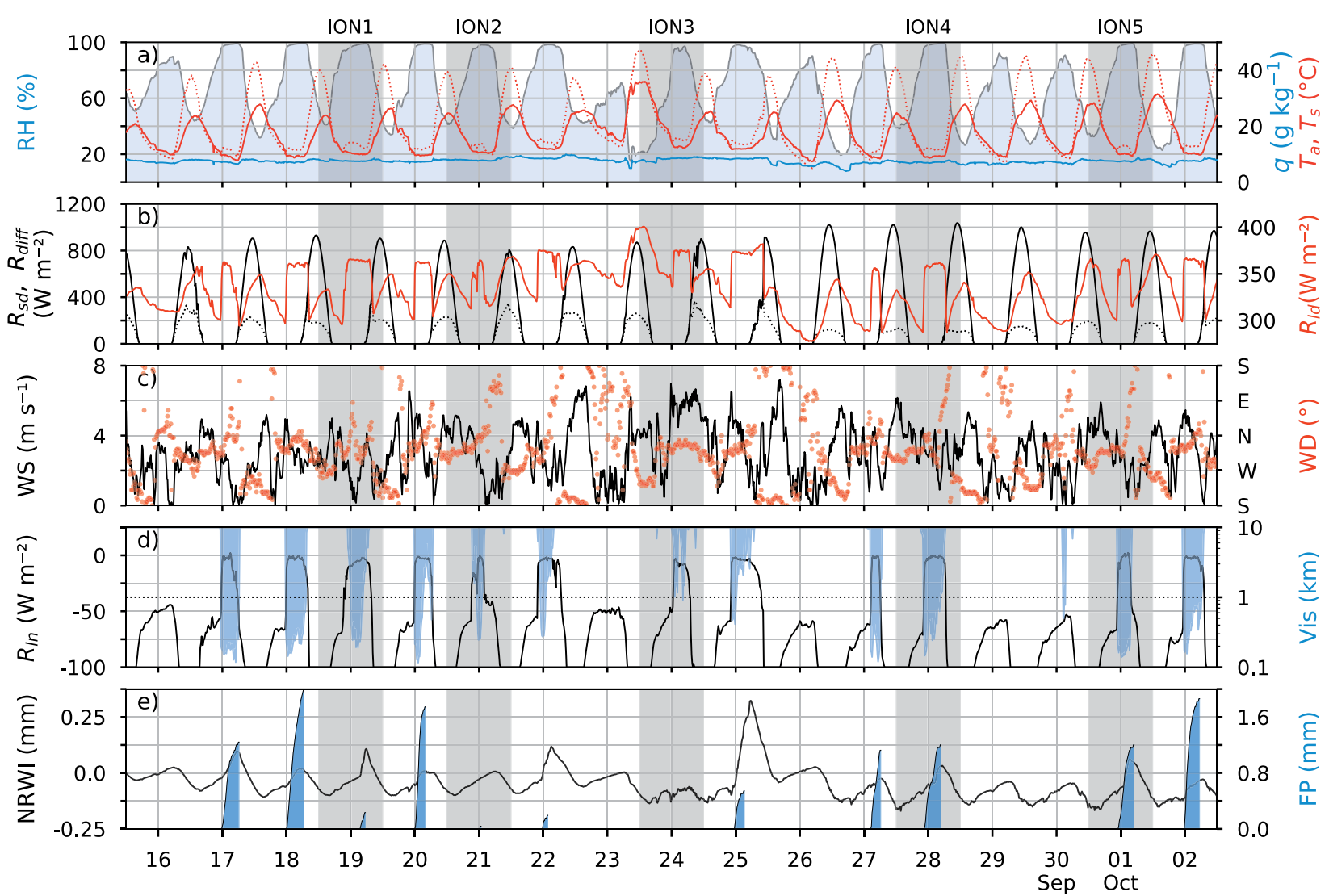

FIG. 3. Overview of selected meteorological variables covering the five IONs (marked gray) of (a) relative humidity (filled blue), air temperature (solid red), surface temperature (dotted red), and specific humidity (blue); (b) global radiation (solid black), diffuse shortwave radiation (dotted black), and longwave downward radiation (red); (c) wind speed (black) and wind direction (orange); (d) net longwave radiation (black) and visibility (filled blue); and (e) daily cumulative fog precipitation (blue) and NRWI (black).

mountain wind (northwestern origin) was observed in the afternoon. During nighttime, winds from northwest to north dominated this IOP and winds from around east blew only in the early-morning transition phase (Fig. 3c). When fog precipitation occurred in Gobabeb, the wind came predominantly from northwest to north, which was also the case in Coastal Met, although there a $20^{\circ}$ shift toward the north is observed (Fig. 4). It is unclear to what extent the thermo-topographic wind system contribute to these regularly occurring flows. Wind speedsduring and without fog-ranged between 2 and $6 \mathrm{~m} \mathrm{~s}^{-1}$ with minima around sunrise and maxima in the late afternoon (Fig. 3c).

Stratus/fog arrival leads to a longwave radiation balance close to zero, which we used as a proxy for the time of arrival. But measurements of $R_{\mathrm{ld}}$ or $R_{n}$

Fig. 4. Wind direction and wind speed distributions during hours with fog precipitation in (a) Coastal Met and (b) Gobabeb during the IOP (10 Sep-5 Oct 2017).

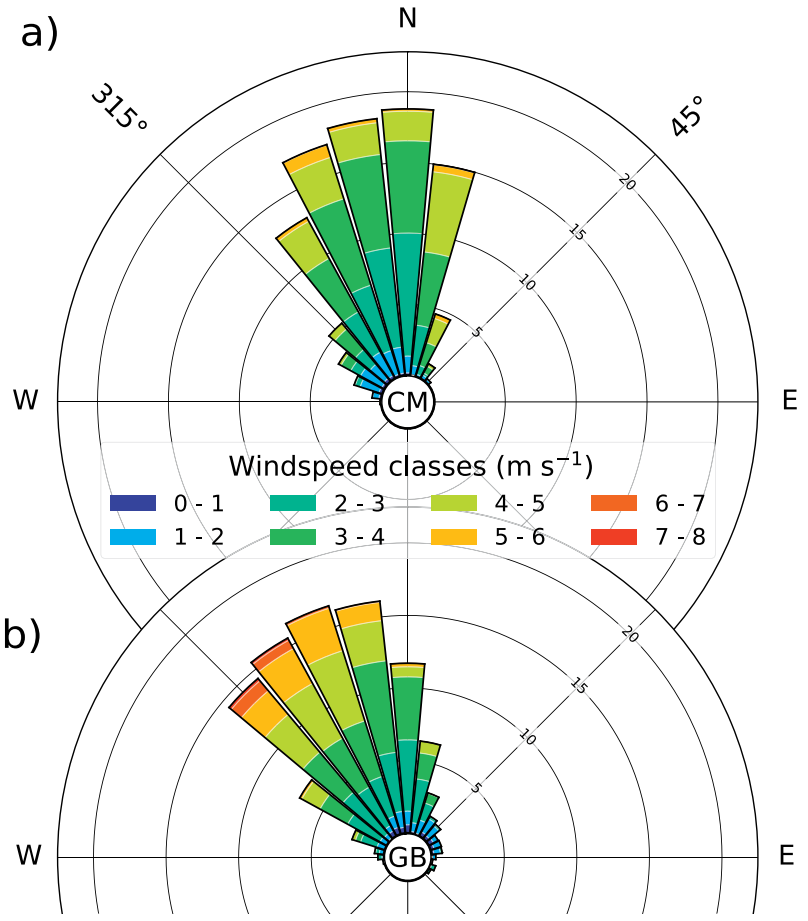


alone are not sufficient to distinguish between stratus and fog. The close relationship with visibility is obvious (Fig. 3d). Visibility values lower than $1 \mathrm{~km}$,
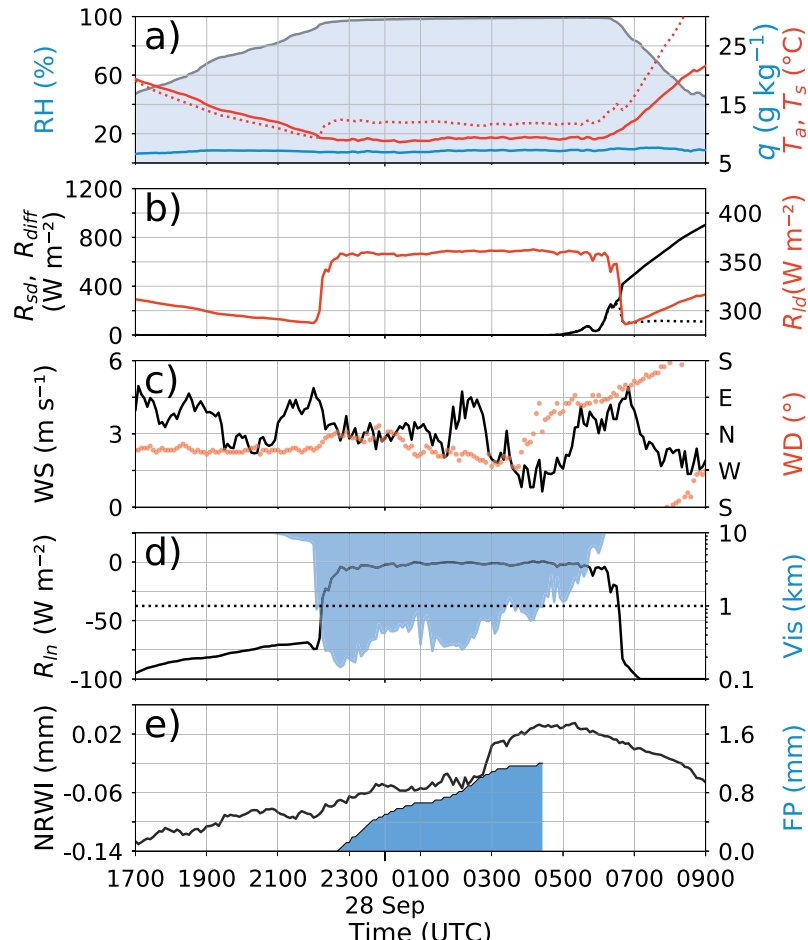

FIG. 5. As in Fig. 3, but a close-up of ION4. that is, fog as defined by the World Meteorological Organization (2018), suggest a correlation with fog precipitation values. Quantifying this relation is not straightforward and a low visibility does not necessarily correspond to a high fog precipitation, for example, 1-2 October with $1.86 \mathrm{~mm}$ FP during almost $5 \mathrm{~h}$ versus 16-17 September with $1.24 \mathrm{~mm}$ of FP during $6.5 \mathrm{~h}$. Despite the shorter duration and generally higher visibility values, the former event resulted in roughly $50 \%$ more fog precipitation.

The non-rainfall water input to the microlysimeters during nights without fog followed a general pattern and peaked shortly before sunrise (Fig. 3e). The diurnal changes illustrate that microlysimeters were able to detect even the smallest amounts of adsorption water/dew. During the fog events, NRWI represents fog water deposition and could reach almost $1 \mathrm{~mm}$. A clear correlation between fog water deposition and fog precipitation is lacking. One possibility could be the collection efficiency depending on droplet size spectra (Montecinos et al. 2018). Another reason could be drizzle. For example, during the night from 24 to 25 September in Gobabeb, a small amount of fog precipitation was measured whereas NRWI was relatively high. Observations during the night suggest a low stratus with drizzle rather than fog.
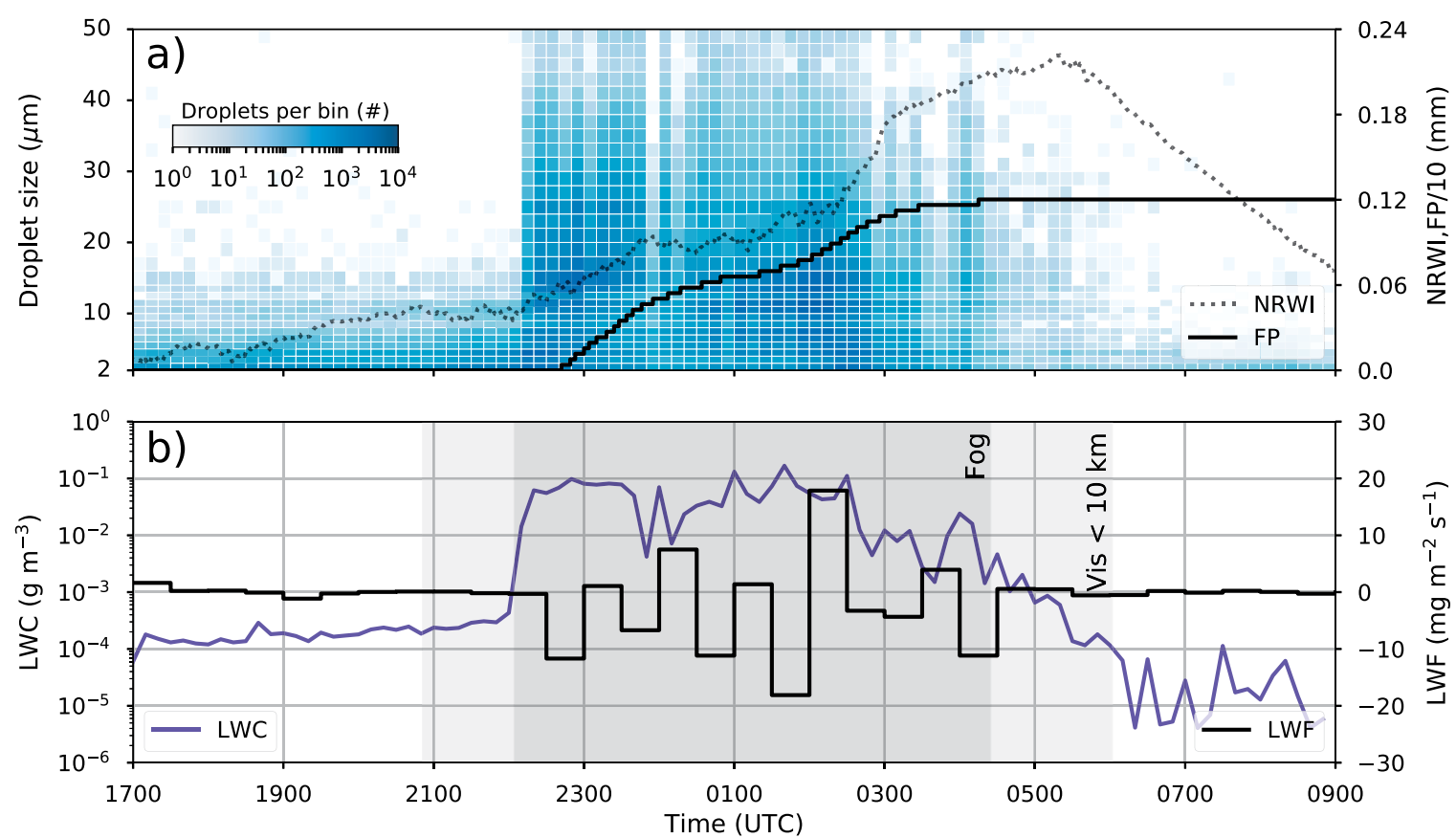

FIG. 6. Cloud droplet probe measurements in 10-min intervals during ION4 at Gobabeb of (a) droplet size distributions in $\mu \mathrm{m}, \mathrm{NRWI}$ (dotted), and cumulative FP (solid) and (b) liquid water content (purple) and liquid water flux over 30 min (black) measured at 2 m AGL. Visibility below I km (dark gray) and below $10 \mathrm{~km}$ (light gray) are drawn in the background in (b). 
Fog on the ground. Surface conditions during the ION4 from 27 to 28 September were characterized by the sudden arrival of the stratus/fog at 2200 UTC in Gobabeb. The front-like occurrence is evident from the sudden changes in most variables (Figs. $5 \mathrm{a}-\mathrm{d}$ ): $\mathrm{RH}$ reached saturation, cooling rate decreased to zero, $T$ increased, WD turned slightly to north, and a jump in longwave radiation coincided with a drop in visibility. The dissipation phase, in turn, was a more gradual process and started around 0430 UTC, when visibility increased and ended at 0630 UTC, marked by the changes in longwave and shortwave radiation. During the presence of fog, air temperature stayed constant at around $9^{\circ} \mathrm{C}$ while the surface was around $3 \mathrm{~K}$ warmer. Fog precipitation started $30 \mathrm{~min}$ after the visibility drop and ended when it increased above $1 \mathrm{~km}$ again. Fog deposition occurred possibly also from $2230 \mathrm{UTC}$ on, but more obviously from 0200 UTC on, and continued until 0530 UTC, when the stratus was already in the dissipation phase (Fig. 5e).

The droplet distribution near the ground during ION4 was characterized by a sudden increase of droplet numbers upon fog arrival at 2200 UTC (Fig. 6a), whereas the first fog precipitation was registered 30 min later. A reduction of droplet numbers between 2350 and 0010 UTC also led to a decrease in fog precipitation with a similar lag. Thus, two collection phases existed for fog precipitation, one from 2230 to 0050 UTC, and a second one from 0130 UTC onward, which was similar for fog water deposition derived from the microlysimeters. LWC measured by the cloud droplet probe increased by three orders of magnitude at the start of the fog event (Fig. 6b). Total liquid water flux was directed toward the surface and with $0.06 \mathrm{~mm}$ in the same order of magnitude as reported by Burkard et al. (2001). Despite decreasing LWC from 0300 UTC on, an increase in fog water deposition was observed which is evidence for drizzle during the fog event.

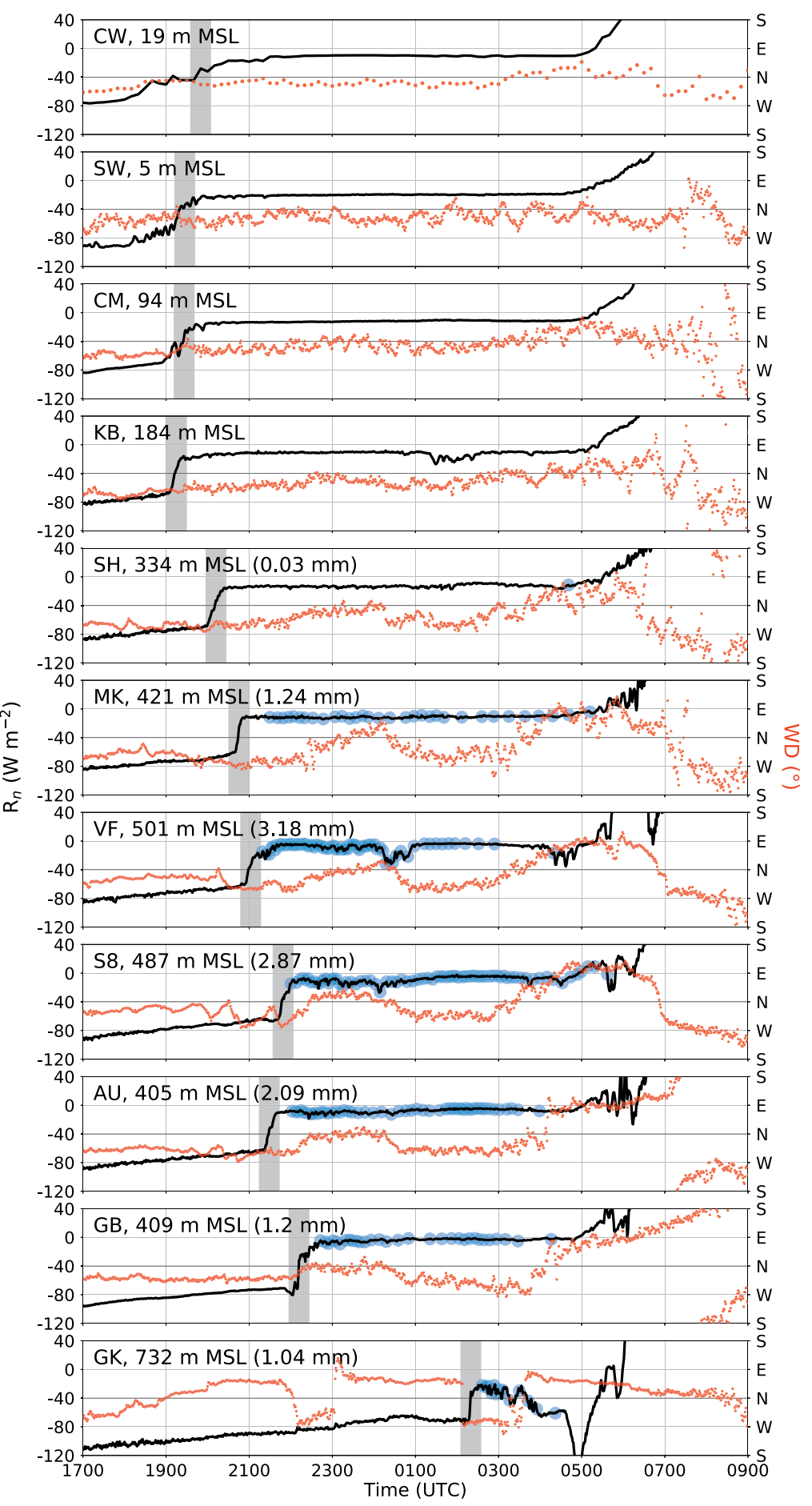

Fig. 7. Net radiation (black) and wind direction (orange) at all FogNet stations on ION4 (27-28 Sep 2017). Gray bars are drawn at the first occurrence of stratus/fog and blue markers indicate registration of fog precipitation (total amount in brackets).

Stratus touchdown. The sudden change in net radiation from below $\approx-70$ to values just below $0 \mathrm{~W} \mathrm{~m}^{-2}$ is a good indicator for the occurrence of either fog or stratus. During ION4, the stratus arrived almost simultaneously from north at 1915 UTC at the stations 


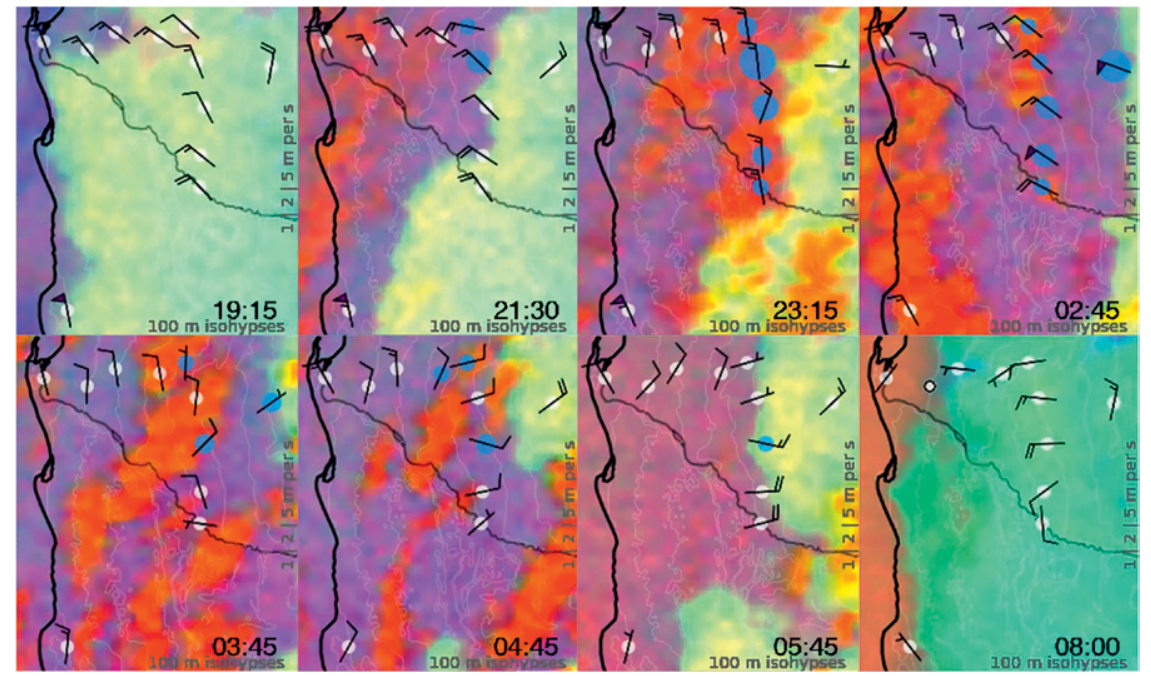

FIG. 8. Example wind fields in the central Namib during ION4. Wind barbs represent $15-\mathrm{min}$ averages of wind speed and wind direction at the FogNet stations. Half line, full line, and triangle indicate I, 2, and $5 \mathrm{~m} \mathrm{~s}^{-1}$. Station marker is blue if fog precipitation occurred during the previous $15 \mathrm{~min}$. Size of blue markers is proportional to the amount of fog precipitation. Purple background colors represent the stratus/fog. Red background colors indicate higher cloud bands, blocking the satellite view of lower layers. An unobstructed view of the surface is seen where background is green. These background colors are derived from Meteosat data (see "Fog goes movie" sidebar for more information) and the geographical context is given in Fig. 2.

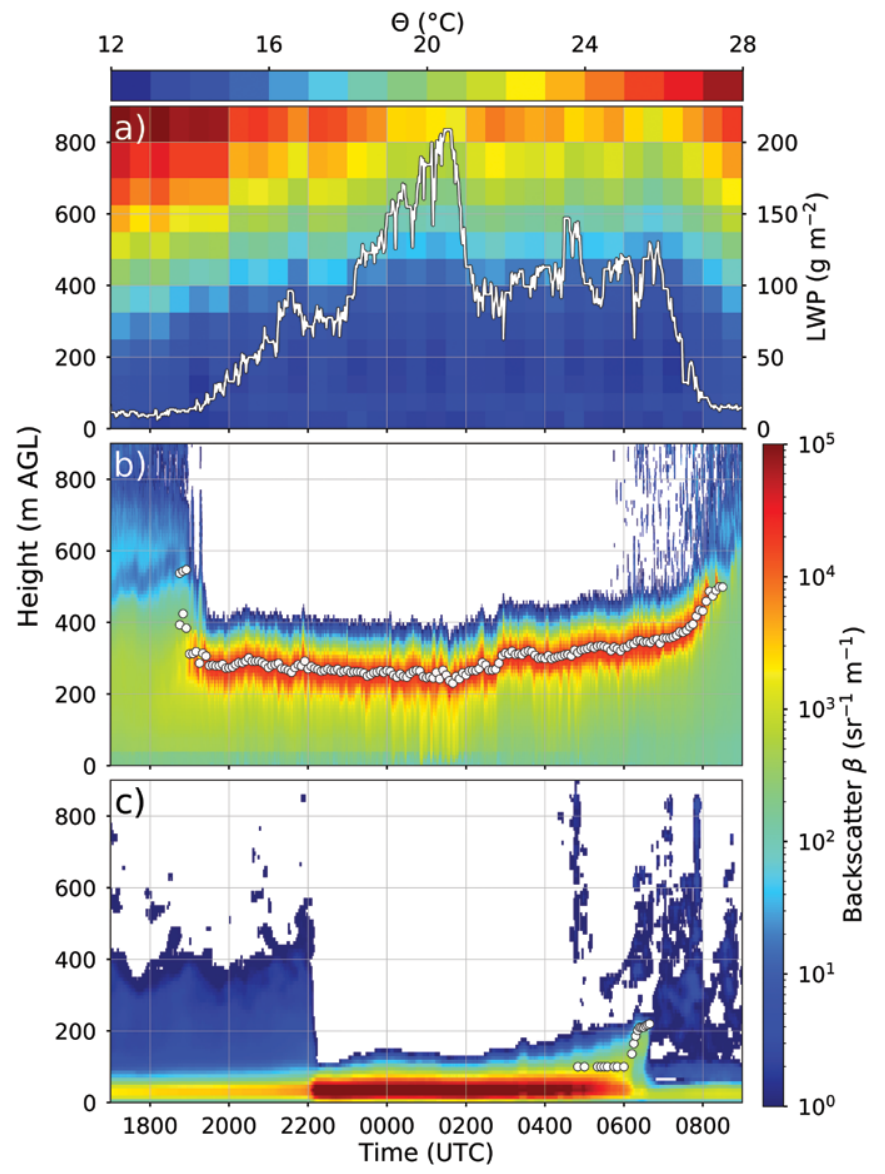

Saltworks, Coastal Met, and Kleinberg, all close to the coast (Figs. 7 and $8)$. From the ceilometer measurements at Coastal Met, a stratus base height of $300 \mathrm{~m} \mathrm{AGL} / 400 \mathrm{~m}$ MSL was obvious (Fig. 9b), and the sodar showed that the clouds were advected from the northwest with wind speeds around $5 \mathrm{~m} \mathrm{~s}^{-1}$ in the lower $200 \mathrm{~m}$ (Fig. 12a). The direction of the coastline with its eastward bend at Walvis Bay facilitates the landfall of the stratus/fog layer here. The jumps in net radiation toward zero at the FogNet stations track the eastward-moving stratus deck, which propagated at an estimated $4 \mathrm{~m} \mathrm{~s}^{-1}$ andcorresponding to the stratus base height at Coastal Met-started to intercept the terrain at $400 \mathrm{~m}$ MSL. Now, the stratus turned into fog and produced fog precipitation along the north-south transect of the FogNet stations (Fig. 7). Fog precipitation occurred first around 2130 UTC at Vogelfederberg and Marble Koppie at the northernmost sites (Fig. 8), then moved farther south and was measured an hour later around 2215 UTC at Gobabeb. Topography modifies the local fog dynamics, for example, at Vogelfederberg, which is on a slight ridge; the overflowing from northwestern directions led to higher FP values, while station 8 in the wake of the ridge received less FP and a little later. The descending terrain toward Gobabeb leads to a further decrease in measured FP (Fig. 7, Table 4). After reaching $500 \mathrm{~m}$ MSL, the eastward movement of the fog front slowed down. The retardation was due to a sloshing back of the stratus deck around 2330 UTC, probably induced by

FIG. 9. Measurements during ION4 (27-28 Sep 2017) in (a),(b) Coastal Met and (c) Gobabeb of (a) the potential temperature profile and LWP (microwave profiler). Ceilometer backscatters [color map in (b) and (c)] are overlaid with cloud base heights (circles) when the cloud base is above zero. 
the cold air drainage from east which was measured at the easternmost station Garnet Koppie from 2315 until 0200 UTC (Fig. 8). The fog front reached Garnet Koppie only around 0245 UTC as manifested in the sudden change in wind direction. FP was measured then together with wind speeds up to $5 \mathrm{~m} \mathrm{~s}^{-1}$ from western directions. For a little more than an hour, fog was advected from northwest and dominated the nocturnal cold air drainage regime (Fig. 7). At 0345 UTC the flow from the east started pushing back the fog layer and the fog front moved back behind the 500-m MSL isohypse after 0545 UTC. After sunrise stratus/fog started to dissipate and disappeared above land almost completely around 0800 UTC when wind directions indicated already the start of the sea breeze (Fig. 8). For an animated synopsis of the fog dynamics during ION4, see "Fog goes movie" sidebar.

Vertical variability. The microwave radiometer at Coastal Met (Fig. 9a) registered the appearance of the stratus at 1900 UTC by an increase in liquid water path. The development of a stable boundary layer at night is reflected by the temperature field. The LWP increased until 0100 UTC and decreased afterward when temperature increased between 600 and $800 \mathrm{~m}$ AGL. Stratus base upon arrival was at around $300 \mathrm{~m}$ AGL until gradual lifting by $50 \mathrm{~m}$ started around 0200 UTC (Fig. 9b). After 0700 UTC, with increasing solar radiation, dissipation accelerated and the last detected cloud base height was at $500 \mathrm{~m} \mathrm{AGL} / 600 \mathrm{~m}$ MSL. In Gobabeb, at $400 \mathrm{~m}$ MSL, the stratus appeared as fog as shown by the ceilometer (Fig. 9c) with a cloud base height of zero. Dissipation of fog in Gobabeb took place between 0600 and 0700 UTC and the last detected cloud base height was at $200 \mathrm{~m} \mathrm{AGL/600} \mathrm{MSL,} \mathrm{suggesting} \mathrm{that}$ stratus thickness at the end of the event was similar at Coastal Met and Gobabeb.

The radiosonde profiles (Fig. 10) throughout ION4 revealed a temperature inversion and a strong reduction of relative humidity between 300 and $500 \mathrm{~m}$ AGL (Fig. 10a). This inversion indicated the stratus thickness as well as a strong decoupling between the stratus layer and the air above. Temperature above the stratus/inversion was constant throughout the night. Prevailing wind direction near the surface (Fig. 10b) before and during the fog event was from a northern sector and turned to an eastern mountain wind at 0500 UTC. The near-surface wind speed during the event reached between 2 (near-ground) and $4 \mathrm{~m} \mathrm{~s}^{-1}$ (stratus top), whereas a low-level maximum of $5 \mathrm{~m} \mathrm{~s}^{-1}$ was observed before the event at 2300 UTC. Above the stratus up to $1,200 \mathrm{~m}$ AGL wind came from the

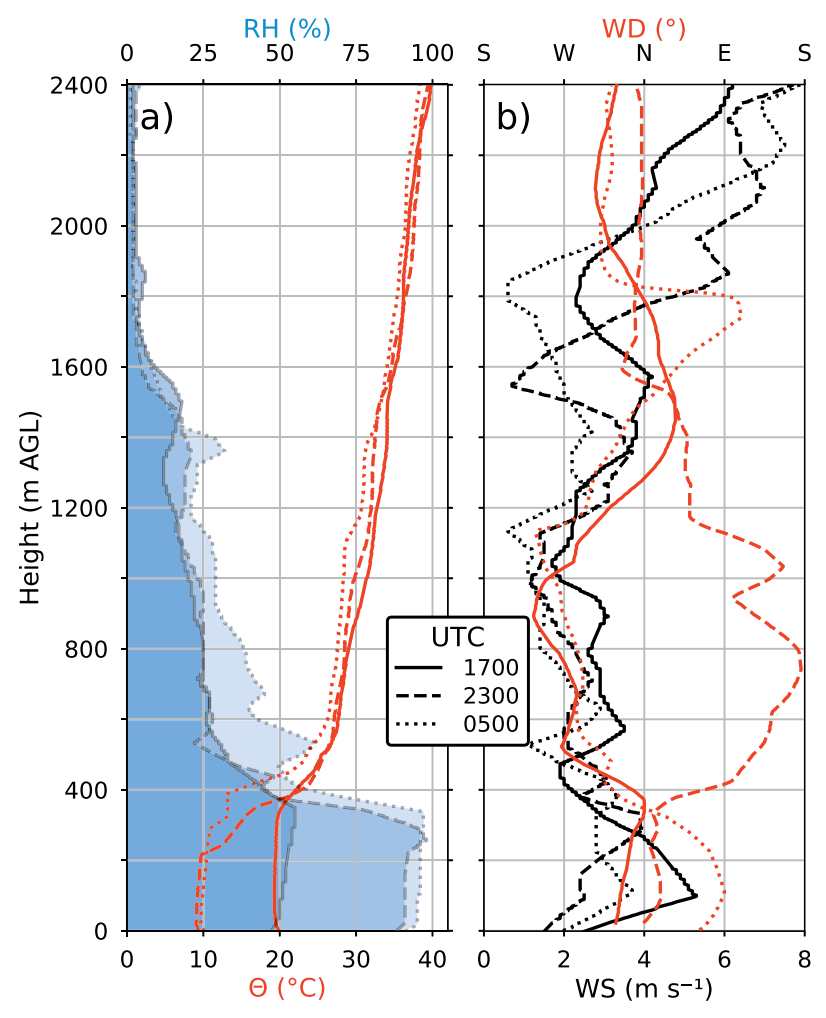

FIG. 10. Vertical profiles from radiosondes launched at Gobabeb during ION4 of (a) relative humidity and potential temperature and (b) wind speed and wind direction. Start times are distinguished by a unique line style.

south at 2300 UTC while before and after the event the flow was from the west with wind speeds toward $2.5 \mathrm{~m} \mathrm{~s}^{-1}$ during all three soundings. Above $1,800 \mathrm{~m}$ AGL, wind speeds increased up to $8 \mathrm{~m} \mathrm{~s}^{-1}$, prevailing from northern directions.

The lowest $800 \mathrm{~m}$ were probed using a TBS in Gobabeb and a UAV in Vogelfederberg. The frequent sampling intervals provide a clearer insight into the single stages of the fog event (Fig. 11). The prefog phase lasted from 1800 to 2200 UTC (Fig. 11a): wind near the ground came steadily from the north with a turn toward northeast above $200 \mathrm{~m}$ AGL and winds above $400 \mathrm{~m}$ AGL were in agreement with the radiosonde profiles. At a height of 300-400 m AGL in Gobabeb, the jet observed by the radiosonde was confirmed in more detail. A gradual slow-down of the jet preceded the stratus arrival. A concurrent increase of relative humidity due to cooling was observed. Shortly after stratus arrival at 2157 UTC air was saturated up to $250 \mathrm{~m}$ AGL (Fig. 11b). The relative humidity profile at both stations indicates a gradual increase in stratus thickness from 170 to 400 m AGL over $5 \mathrm{~h}$ in Gobabeb and 70 to $300 \mathrm{~m}$ in Vogelfederberg which corresponds to the same heights above 
sea level. During this phase, the wind in the stratus layer came steadily from northerly directions with wind speeds generally between 2 and $4 \mathrm{~m} \mathrm{~s}^{-1}$ after the ascent at 2157 UTC. The inversion increased with a constant potential temperature gradient of $0.5 \mathrm{~K}(100 \mathrm{~m})^{-1}$. Between 0330 and $0400 \mathrm{UTC}$, vertical growth culminated and lowering of the stratus ceiling began while the air remained fully saturated until the final ascents in Gobabeb (Fig. 11c). The inversion at $300 \mathrm{~m}$ AGL in Gobabeb lasted at least until 0722 UTC. Surface heating at Vogelfederberg began at around 0630 UTC and relative humidity consequently decreased while the temperature inversion remained at $300 \mathrm{~m}$ AGL until the end of the measurements at 0700 UTC. Dissipation of fog at both sites began around 0700 UTC. Winds in Gobabeb during the dissipation turned from north to east and gradually increased from 2 to $4 \mathrm{~m} \mathrm{~s}^{-1}$, with an observed peak of $6 \mathrm{~m} \mathrm{~s}^{-1}$ at $200 \mathrm{~m} \mathrm{AGL}$. During the second half of the night, a decoupled layer of dry warm air with wind from the east was observed above the stratus in agreement with radiosonde observations from 2300 UTC. As a summary, the course of the stratus top at Gobabeb derived from $\mathrm{RH}$ of the TBS descents is displayed in Fig. 12c.

Synoptic conditions apparently led to wind from northwest to north-northeast over the course of the night in Coastal Met (Fig. 12a). Wind data from the TBS and the sodar in Gobabeb demonstrated the complexity of the wind field during ION4 (Figs. 12b,c) where three prominent features can be observed: (i) a jet from north-northeast between 1900 and 2100 UTC at 200 up to $300 \mathrm{~m} \mathrm{AGL}$ during the prefog phase while winds below came from north-northwest, (ii) a decoupled layer with eastern wind above $400 \mathrm{~m}$ AGL during the fog event, and (iii) the mountain wind during the dissipation phase from 0500 UTC in the lowest $300 \mathrm{~m}$. The vertical extent of mountain wind agreed with the upper limit of the stratus during its dissipation (Fig. 12c).
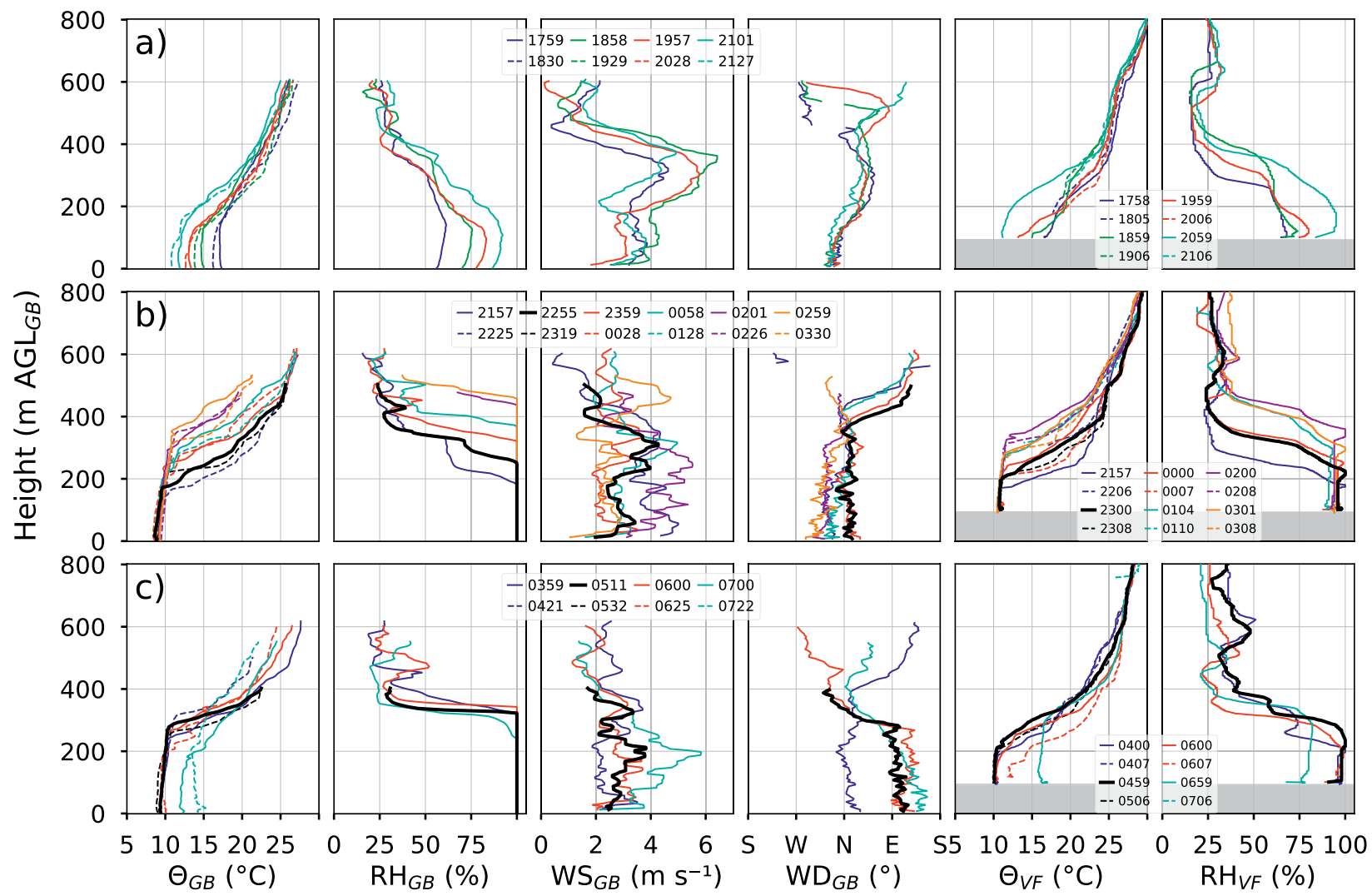

FIG. II. Vertical profiles of the TBS and UAV soundings during ION4 for (from left to right) Gobabeb (potential temperature, relative humidity, wind speed, and wind direction) and Vogelfederberg (potential temperature, relative humidity). To increase clarity, descents are only drawn for potential temperature. Start time of ascent/ descent in UTC is used as labeled. Profiles in Vogelfederberg are offset by the elevation difference to Gobabeb. Ascents are drawn solid, descents dotted, and sampling closest to the radiosonde soundings are marked in black. For clarity, soundings are split into three rows for the stages of the event: (a) prefog, (b) during fog, and (c) dissipation of fog. For $\mathrm{RH}_{\mathrm{GB}}, \mathrm{WS}_{\mathrm{GB}}$, and $\mathrm{WD}_{\mathrm{GB}}$ only ascents are shown. 


\section{SUMMARY AND} OUTLOOK. The intensive observation period (IOP) of the Namib Fog Life Cycle Analysis Project (NaFoLiCA) was carried out to investigate the life cycle of fog in the central Namib. Meteorological equipment was installed at a coastal and an inland site in the central Namib to monitor this life cycle during the NaFoLiCA IOP. Existing measurements of basic meteorological variables of the FogNet were complemented with instrumentation to probe the vertical structure of the stratus/fog. Data were sampled from 10 September to 5 October 2017 with additional observations during five intensive observation nights (ION).

We focused our initial analysis on the general meteorological conditions during the IOP and selected one night (ION4) to present the typical processes observed during the different stages of the fog life cycle. Fog occurred at least at two FogNet stations on 22 nights. Without exception, all fog events were linked to an apparent landfall of the eastern border of the connected marine stratus deck. When and where this landfall occurred varied considerably and is likely determined by thickness and cloud base height of the stratus. On average it appeared as eastward propagation of the stratus as found in Andersen et al. (2019).

During ION4 a fog life cycle was monitored in detail from the first arrival as stratus at 1900 UTC until dissipation at 0900 UTC the day after. The observations during this ION4 and the IOP represent the complex interplay between the largescale driven stratus advection, the terrain and the thermo-topographic wind systems: the stratus base apparently determines where land is intercepted first, that is, where the stratus turns into fog, and the strength and height of the inversion is indicative of how far this process reaches inland. The initially weak cold air drainage from the east is replaced by the advected stratus/fog and catches up after the eastward movement stopped. East wind pushes back the fog layer simultaneously with its progressive dissipation.

On the plot scale, we measured fog deposition with microlysimeters and fog precipitation with Juvik fog collectors with the intention to use the latter as a proxy for the former. However, we found only a poor correlation and thus assume that during some events drizzle occurred, which has an effect only on the microlysimeter measurements. Fog water deposition can in principle be estimated by measuring the liquid water flux density with the eddy-covariance method; however, failure of the sonic anemometer during heavy wetting events is a problem.

During the NaFoLiCA IOP, we successfully collected an extensive dataset that covers several fog life cycles in the central Namib in unprecedented detail. The initial analysis will be expanded, including all IONs with the aim to better understand what drives fog life cycle stages and how local processes could be involved. The dataset will be used by the partner projects to investigate the relevance of the thermo-topographic wind systems for the formation, occurrence, and dissipation of fog (NaFoLiCAModeling) and also to study how individual fog situations develop over time, with regard to their geometrical, optical, and microphysical properties (NaFoLiCA-Satellite). 
ACKNOWLEDGMENTS. Funding for NaFoLiCA came from Swiss National Science Foundation (SNSF) for RS and JAL (Grant 163291) and from Deutsche Forschungsgemeinschaft (DFG) for HA (Grant CE 163/7-1) for MH (Grant BO 998/15-1). Edward Martins from Telecom Namibia provided easy access to the area of Coastal Met. We thank the staff of the Gobabeb Research and Training Center for the support during the IOP. We thank the three anonymous reviewers for their valuable criticism and suggestions for improvement of the article.

\section{REFERENCES}

Adebiyi, A. A., and P. Zuidema, 2018: Low cloud cover sensitivity to biomass-burning aerosols and meteorology over the southeast Atlantic. $J$. Climate, 31, 4329-4346, https://doi.org/10.1175 /JCLI-D-17-0406.1.

Andersen, H., and J. Cermak, 2015: How thermodynamic environments control stratocumulus microphysics and interactions with aerosols. Environ. Res. Lett., 10, https://doi.org/10.1088/1748-9326/10/2/024004.

- , and _ 2018: First fully diurnal fog and low cloud satellite detection reveals life cycle in the Namib. Atmos. Meas. Tech., 11, 5461-5470, https://doi.org /10.5194/amt-11-5461-2018.

— - — I. Solodovnik, L. Lelli, and R. Vogt, 2019: Spatiotemporal dynamics of fog and low clouds in the Namib unveiled with ground- and space-based observations. Atmos. Chem. Phys., 19, 4383-4392, https://doi.org/10.5194/acp-19-4383-2019.

Aubinet, M., T. Vesala, and D. Papale, 2012: Eddy Covariance. Springer Atmospheric Sciences, $451 \mathrm{pp}$.

Burkard, R., T. Wrzesinsky, and O. Klemm, 2001: Quantification of fog deposition with two similar set-ups. Second Int. Conf. on Fog Collection and Dew, St. Johns, Canada, International Fog and Dew Association, 185-188.

Cermak, J., 2012: Low clouds and fog along the SouthWestern African coast-Satellite-based retrieval and spatial patterns. Atmos. Res., 116, 15-21, https://doi .org/10.1016/j.atmosres.2011.02.012.

Driemel, A., and Coauthors, 2018: Baseline Surface Radiation Network (BSRN): Structure and data description (1992-2017). Earth Syst. Sci. Data, 10, 1491-1501, https://doi.org/10.5194/essd-10-1491-2018.

Droplet Measurement Technologies, 2012: Cloud Droplet Probe (CDP) manual. Manual DOC-0029, Rev 0, Droplet Measurement Technologies, 56 pp.

Eckardt, F. D., and Coauthors, 2013: The nature of moisture at Gobabeb, in the central Namib Desert. J. Arid Environ., 93, 7-19, https://doi.org/10.1016/j .jaridenv.2012.01.011.
Formenti, P., and Coauthors, 2019: The Aerosols, Radiation and Clouds in Southern Africa Field Campaign in Namibia: Overview, illustrative observations, and way forward. Bull. Amer. Meteor. Soc., 100, 12771298, https://doi.org/10.1175/BAMS-D-17-0278.1.

Fuchs, J., J. Cermak, H. Andersen, R. Hollmann, and K. Schwarz, 2017: On the influence of air mass origin on low-cloud properties in the southeast Atlantic. J. Geophys. Res. Atmos., 122, 11 076-11 091, https://doi .org/10.1002/2017JD027184.

,-- , and -2018 : Building a cloud in the southeast Atlantic: Understanding low-cloud controls based on satellite observations with machine learning. Atmos. Chem. Phys., 18, 16537-16552, https:// doi.org/10.5194/acp-18-16537-2018.

Goudie, A., and H. Viles, 2015: Landscapes and Landforms of Namibia. Springer, $164 \mathrm{pp}$.

Hachfeld, B., and N. Jürgens, 2000: Climate patterns and their impact on the vegetation in a fog driven desert: The Central Namib Desert in Namibia. Phytocoenologia, 30, 567-589, https://doi.org/10.1127 /phyto/30/2000/567.

Heusinkveld, B. G., S. M. Berkowicz, A. F. G. Jacobs, A. A. M. Holtslag, and W. C. A. M. Hillen, 2006: An automated microlysimeter to study dew formation and evaporation in arid and semiarid regions. J. Hydrometeor., 7, 825-832, https://doi.org/10.1175 /JHM523.1.

Jackson, S. P., 1941: A note on the climate of Walvis Bay. S. Afr. Geogr. J., 23, 46-53, https://doi.org/10.1080 /03736245.1941.10559213.

Juvik, J. O., and D. Nullet, 1995: Comments on "A proposed standard fog collector for use in high-elevation regions." J. Appl. Meteor., 34, 2108-2110, https://doi .org/10.1175/1520-0450(1995)034<2108:COPSFC $>2.0 . \mathrm{CO} ; 2$.

Kalthoff, N., and Coauthors, 2013: KITcube - A mobile observation platform for convection studies deployed during HyMeX. Meteor. Z., 22, 633-647, https://doi .org/10.1127/0941-2948/2013/0542.

Kaseke, K. F., L. Wang, and M. K. Seely, 2017: Nonrainfall water origins and formation mechanisms. Sci. Adv., 3, e1603131, https://doi.org/10.1126/sciadv.1603131.

Kimura, K., 2005: Origin of the fog in Namib Desert in dry season. Afr. Study Monogr., 30 (Suppl.), 57-64.

Lancaster, J., N. Lancaster, and M. K. Seely, 1984: Climate of the central Namib Desert. Madoqua, 14, 5-61.

Meigs, P., 1966: Geography of Coastal Deserts. UNESCO, $140 \mathrm{pp}$.

Mendelsohn, J., A. Jarvis, C. Roberts, and T. Robertson, 2002: Atlas of Namibia: A Portrait of the Land and Its People. Sunbird Publishers, 200 pp. 
Montecinos, S., D. Carvajal, P. Cereceda, and M. Concha, 2018: Collection efficiency of fog events. Atmos. Res., 209, 163-169, https://doi.org/10.1016/j .atmosres.2018.04.004.

Muche, G., and Coauthors, 2018: SASSCAL WeatherNet: Present state, challenges, and achievements of the regional climatic observation network and database. Biodivers. Ecol., 6, 1.6, https://doi.org/10.7809/B-E.00302.

Nagel, J. F., 1959: Fog precipitation in Swakopmund. South African Weather Bureau Newsletter, No. 125, 1-9.

— 1962: Fog precipitation measurement on Africa's south-west coast. NOTOS, 11, 51-60.

Nicholson, S. E., 2010: A low-level jet along the Benguela coast, an integral part of the Benguela current ecosystem. Climatic Change, 99, 613-624, https://doi .org/10.1007/s10584-009-9678-z.

Nieman, W. A., C. Heyns, and M. Seely, 1978: A note on precipitation at Swakopmund. Madoqua, 1978 (1), 69-73.

Olivier, J., 1992: Some spatial and temporal distribution of fog in the Namib. S. Afr. Geogr., 119 (1/2), 107-127.

- 1995 : Spatial distribution of fog in the Namib. J. Arid Environ., 29, 129-138, https://doi.org/10.1016 /S0140-1963(05)80084-9.

Seely, M. K., 1989: Is there anything special about the Namib Desert? S.-Afr. Tydskr. Wet., 85, 215.

- , and J. Henschel, 1998: The climatology of Namib fog. Proc. First Int. Conf. on Fog and Fog Collection, Vancouver, Canada, International Fog and Dew Association, 353-356.

Stier, P., and Coauthors, 2013: Host model uncertainties in aerosol radiative forcing estimates: Results from the AeroCom Prescribed intercomparison study. Atmos. Chem. Phys., 13, 3245-3270, https://doi .org/10.5194/acp-13-3245-2013.

Tyson, D. P., and R. A. Preston-Whyte, 2000: The Weather and Climate of Southern Africa. Oxford University Press, 396 pp.

Tyson, P., and M. Seely, 1980: Local winds over the central Namib. S. Afr. Geogr. J., 62, 135-150, https:// doi.org/10.1080/03736245.1980.10559630.

Warner, T. T., 2004: Desert Meteorology. Cambridge University Press, $623 \mathrm{pp}$.

Warren-Rhodes, K. A., and Coauthors, 2013: Physical ecology of hypolithic communities in the central Namib Desert: The role of fog, rain, rock habitat, and light. J. Geophys. Res. Biogeosci., 118, 1451-1460, https://doi.org/10.1002/jgrg.20117.

Wiegner, M., and Coauthors, 2019: Aerosol backscatter profiles from ceilometers: Validation of water vapor correction in the framework of CeiLinEx2015. Atmos. Meas. Tech., 12, 471-490, https://doi.org /10.5194/amt-12-471-2019.

World Meteorological Organization, 2018: Technical Regulations, Basic Documents No. 2, Volume IIMeteorological Service for International Air Navigation. WMO-49, 205 pp.

Zuidema, P., J. Redemann, J. Haywood, R. Wood, S. Piketh, M. Hipondoka, and P. Formenti, 2016: Smoke and clouds above the southeast Atlantic: Upcoming field campaigns probe absorbing aerosol's impact on climate. Bull. Amer. Meteor. Soc., 97, 1131-1135, https://doi.org/10.1175/BAMS -D-15-00082.1. 


\section{JOIN US FOR THE CULMINATION OF OUR CENTENNIAL CELEBRATION}

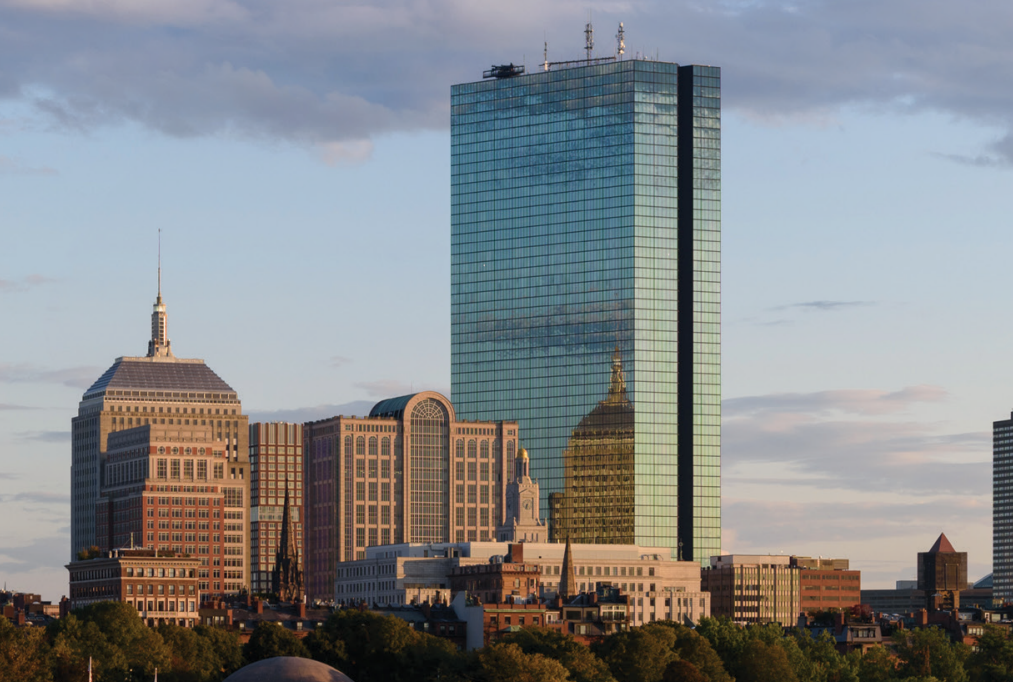

